\title{
Cooperative Second-Cycle Breeding and Test- ing of Coastal Douglas-fir in the US Pacific Northwest: Strategy, Implementation, and Op- erational Aspects
}

\author{
KJS Jayawickrama* and TZ Ye
}

Northwest Tree Improvement Cooperative, Department of Forest Ecosystems and Society, Oregon State University, Corvallis, OR 97331-5752, USA

* Corresponding author: KJS Jayawickrama, E-mail: keith.jayawickrama@oregonstate.edu

\begin{abstract}
The second cycle of cooperative breeding and testing of coastal Douglas-fir in western Oregon and Washington was started around 1992. By 2020 the bulk of testing is nearing completion, while the latest program in southern Oregon and NW California is scheduled to run through 2035. A total of 109 firstgeneration programs were consolidated into nine secondcycle breeding and testing cooperatives (with 15 testing zones); 136 tests are planned, of which 120 have already been established. Between five and eight tests are established per trial series. Trials established to date have contained from 50 to 283 full-sib crosses. In total, the Douglas-fir breeding effort will be comprised of over 2,900 crosses, of which 2,500 have already been established in the field. A total of about 349,000 test trees are to be planted, with over 310,000 already planted.

Tests typically get three main measurements when the trees are 3 (or 4), 7 and 12 years old from seed. (1) Age-3 or 4: progression of budburst, on a 1 to 5 rating score, when roughly $50 \%$ of the seedlings have broken bud, on one or two sites per trial series. (2) Age-7: height (height pole), dbh, stem sinuosity in the second internode from the top, number of incidences of stem forking, number of incidences of ramicorn branching and (3) Age-12: height (vertex), dbh, stem sinuosity in the second internode from the top, number of incidences of stem forking, number of incidences of ramicorn branching, second flushing yes $\backslash$ no in current year, and wood acoustic velocity (in some trial series).
\end{abstract}

Keywords: : Advanced-generation, Pseudotsuga menziesii, progeny testing, full-sib crosses, plantation, selection, tree breeding

\section{INTRODUCTION}

Coastal Douglas-fir (Pseudotsuga menziesii Mirb. (Franco)) is by far the most important species for plantation forestry and tree improvement in the US Pacific Northwest, and dominates the ecosystem of those forests. It can thrive under a variety of environmental conditions, occurs over an enormous north-south range, is easy to grow in nurseries and in pure stands, and has so far proved remarkably resistant to endemic diseases and pests (though the threat of an introduced threat is constant). Aspects of evolution, biology, planting are described by Lavendar and Hermann (2014) while forest management, silviculture and utilization are dealt with in many papers.

The genetics and breeding of coastal Douglas-fir in western North America has been documented in many reports and publications going back to the 1950s, and was summarized by Howe et al. (2006), including the approach to breeding zones, breeding cycles, mating designs, field designs, traits of interest, genetic parameters, and methods of deployment. At the time of that review, cooperative second-cycle breeding and testing in western Oregon and western Washington was in progress.

This paper was written to document the continued evolution and development of that large and intensive second cycle program, to describe modifications from the plans and scenarios described in Howe et al. (2006) since tree improvement programs are dynamic and take a long time to complete, and to highlight operational details of implementation. While Howe et al. (2006) dealt with a number of Douglas-fir breeding programs, we provide an in-depth look at one of them. 


\section{FIRST-GENERATION TESTING OF DOUGLAS-FIR}

The earliest forest genetics study in the US Pacific Northwest (PNW) was the establishment of the Douglas-fir heredity study in 1915 and 1916 by the US Forest Service, with 120 families established on five sites. The conclusion of narrow adaptation of Douglas-fir to place of origin, and of maladaptation becoming evident over decades, was made from this study (Silen 1978). Age-100 data from these stands was recently reported (St Clair et al. 2019).

As in many temperate, developed regions of the world, operational forest tree improvement got underway in the PNW in the early 1950s. At first, the approach was intensive phenotypic selection and establishing grafted clonal orchards. Due to the high incidence of graft incompatibility, a modified approach, the IFA-PNW "Progressive Tree Improvement System" was launched in 1966 (Silen 1966, Silen and Wheat 1979). The emphasis shifted to forming local cooperatives (between forest owners and managers with overlapping landbases) to share costs, and on progeny testing large numbers of trees as soon as possible using wind-pollinated seed collected from wild trees. This approach shared many similarities with that taken for Pinus radiata D. Don. by Tony Shelbourne in New Zealand in the late 1960s (Jayawickrama et al. 1997), in contrast to other breeding programs of that era ${ }^{1}$ in which smaller sets of plus trees were selected and crossed in diallels after first establishing them in grafted clonal orchards, a much slower process involving a smaller base population.

Establishment of first-generation tests ran from 1967 till 1993, during which over 24,000 first-generation Douglas-fir parents were tested in 108 breeding units, with data collected from over 2.242 million progeny test trees. Due to the use of wind-pollinated seed, test establishment proceeded much faster than it would have with a controlled crossing program. The typical measurement schedule was five, 10 and 15 years from seed. Height was usually measured on each occasion, while diameter was usually measured at age 15 and sometimes at age 10 as well. The number of incidences of ramicorn branches, forks and upper stem sinuosity was assessed in some of the later testing programs, due to the potential of these traits to cause log and lumber value degrade (Howe et al. 2006). Data collection was complete by the early 2000 s.

\section{SECOND-CYCLE BREEDING AND TESTING Strategy Development}

By the late 1980s age-15 data collection had completed for several first-generation testing programs, and some forward selections from the first-generation tests had been grafted into breeding orchards. At first, varying approaches were proposed by various first-generation cooperatives for moving into a second cycle of testing, some continuing with the very small breeding zones used in the first cycle since the belief in narrow adaptability had become deeply ingrained in the PNW tree improvement and forestry community, while some took a more expansive approach. Crossing had begun by the early

\footnotetext{
1 Such as the first-generation Douglas-fir programs by Weyerhaeuser, Washington DNR and British Columbia Forest Service and the NC State Cooperative loblolly pine second-cycle program.
}

1990s. second cycle of testing, some continuing with the very small breeding zones used in the first cycle since the belief in narrow adaptability had become deeply ingrained in the PNW tree improvement and forestry community, while some took a more expansive approach. Crossing had begun by the early 1990s.

Subsequently, data from the first-generation tests were used to draw several conclusions relevant to advanced-generation breeding and testing; other decisions were based on computer simulation and inferences from other breeding programs in other parts of the world (Johnson 1997, 1998a, 1998b; Johnson et al. 1997), and a coordinated approach was fashioned. It concluded that:

- Some consolidation of first-generation breeding zones was appropriate, in the north-south direction, into larger testing zones to share genetic material.

- There would be little marginal gain per test beyond six successful progeny tests per second-cycle testing zone (in terms of ranking families). Each test site was to have a minimum of 20 trees per family.

- Crosses would largely be made among parents and forward selections within a first-generation breeding zone. This would lead to breeding groups (based on first-generation breeding zone) to manage inbreeding, and multiple populations to maintain locally adapted gene complexes.

- Rather than adhere to a rigid, pre-planned crossing scheme such as small factorials or disconnected diallels, crossing would proceed within a breeding group as pollen and female strobili came available. This was likely to expedite the breeding cycle by several years, given the experience of some previous Douglas-fir crossing programs (e.g. 10 years to establish disconnected 6-parent diallels for 215 parents in British Columbia, Yanchuk 1996).

- A complementary mating design (i.e., separate GCA and full-sib tests) was not seen to be necessary in the main breeding population, but was recommended for elite populations.

- Two or three crosses would give a reasonable estimate of a parent's GCA.

- Final selection around age 12 years would be efficient.

A second-cycle breeding and testing strategy for coastal Douglas-fir was developed and generally accepted by cooperators between 1996 and 1997. The term second-cycle is used instead of second-generation, since the selections used for crossing were not all at the same generation compared to the original wild population.

It appears a couple of strategy options were not considered: (1) Partially pedigreed populations (open-pollinated or polycross) to make forward selections, or pedigree 
reconstruction using markers; and (2) Cloned breeding populations: coastal Douglas-fir is a poor rooting species even compared with other temperate conifers. While some additional approaches (such as the mated selection algorithms replacing sublines, and genomic selection) are currently being adopted by tree improvement programs, these were not adopted during the $2^{\text {nd }}$ cycle Douglas-fir breeding effort with the bulk of the crossing completed 10 years ago.

\section{Implementation}

Implementation of the second-cycle testing program, over the 23 years since it was formulated, has been fairly similar to the proposed strategy; the proposed strategy proved to be robust, practical and technically sound. A total of 109 first-generation programs were consolidated into nine second-cycle breeding and testing cooperatives (with 15 testing zones). The use of cooperatives to reduce costs and maximize efficiency has continued successfully to the second cycle.

The emphasis has been mostly been on low to mid-elevation lands up to 1,090 meters, since the highest elevation Douglas-fir forests are typically under US Forest Service management with little emphasis on timber production. However, the MEDTIC program in southern Oregon $\backslash$ NW California is planning to establish test sites as high as 1,667 meters, since in that area higher elevations are associated with more precipitation (often as snow), are more conducive to Douglas-fir, and include private industrial timberlands. The environment included in second cycle testing is diverse, with precipitation as low as 750 $\mathrm{mm}$ and as high as $2,500 \mathrm{~mm}$. One area that has been deliberately excluded is the part of the Oregon and Washington Coasts where Swiss Needle Cast disease (caused by the fungus Phaeocryptopus gaeumannii) is severe, and where alternate species such as western hemlock, western red cedar, Sitka spruce or red alder are now recommended (Ritakova et al. 2016).

Breeding populations for second-cycle programs contain at least 130 selections, but most are greater than 300 . Within a breeding population, multiple breeding groups of 12-30 selections were constructed. The goal in choosing second-cycle selections has been a 1 in 10 among-family selection intensity, though this intensity was increased in some cases. Most selections were made on age-15 height; information on DBH, stem form and wood specific gravity were also considered. The top selections within a breeding population were sometimes assigned to an elite population.

Across all the second-cycle cooperatives, crosses from a total of 2,660 parents are being tested (Table 1); these parents were picked from first-generation programs with 21,285 families tested (roughly one selection per eight first-generation families). Most of those parents $(1,755)$ were highly ranked first-generation parents; 883 were selections from wind-pollinated first-generation tests, and 14 were selections from fullsib crosses planted in first-generation seedling seed orchards. The geographic origin of the parents used in breeding and testing are shown in Figure 1.

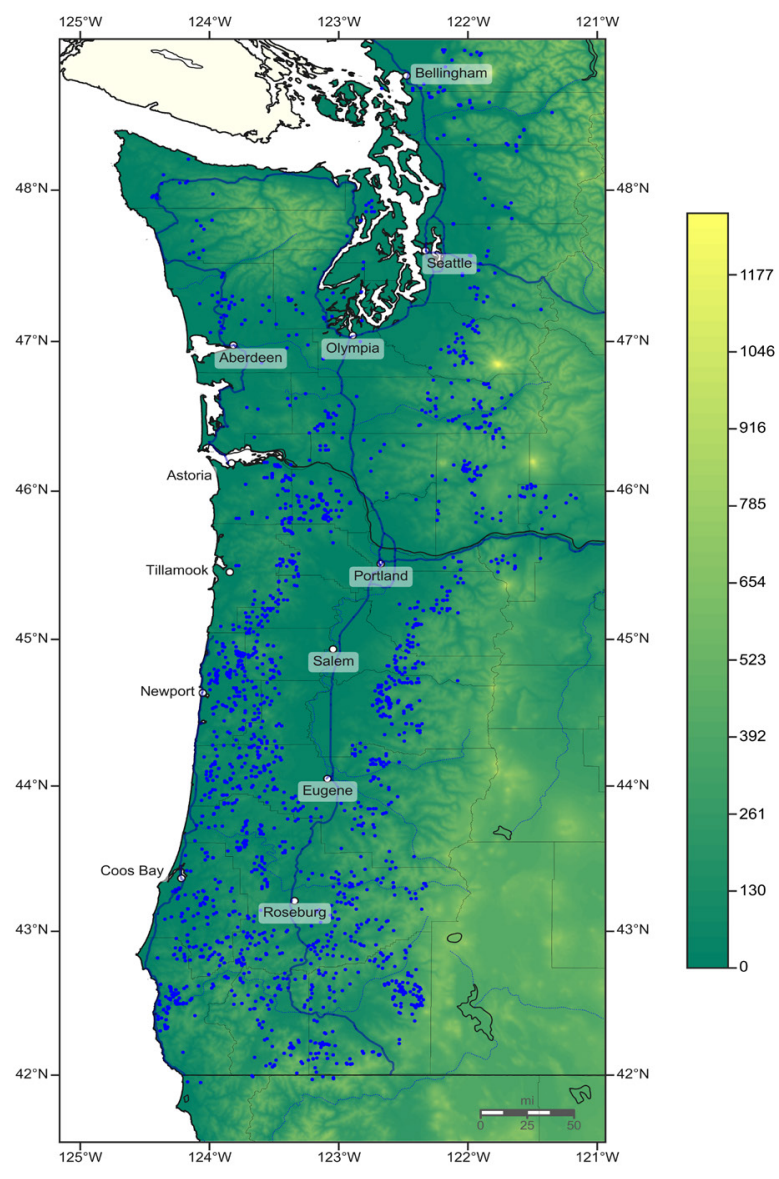

Figure 1

Origin of parents (blue dots) used in cooperative second-cycle breeding and testing

The breeding population for each second-cycle zone includes families/selections from the "local" breeding groups that come from the testing zone, and only the highest-ranked selections from breeding groups originating further away from the testing zone. Each selection is generally being used in two crosses, but some only in one cross, and some in up to four crosses. Some of the elite crosses are made across first-generation zones. There has also been substantial wide testing, with a few crosses shared across as many as four second-cycle cooperatives. Guidelines for control crossing of Douglas-fir are given in Jayawickrama et al. (2013). An example of a hypothetical crossing matrix is shown in Figure 2; crosses are made opportunistically depending on availability of pollen and female flowers.

Unimproved (typically called "woodsrun" in the PNW) checklots have been included in all tests planted after 2001, generally including multiple such checklots per trial series. These are typically well-controlled wild collections made in specific locations by one of the cooperators, at a time when almost all reforestation was based on such collections. Fortunately, Douglas-fir seed maintains high germination rate for many years under proper cold storage at $-18 \mathrm{C}$ (Stein and Owston 2008), so it has been possible to use old unimproved seedlots dating back even to the 1970s. 


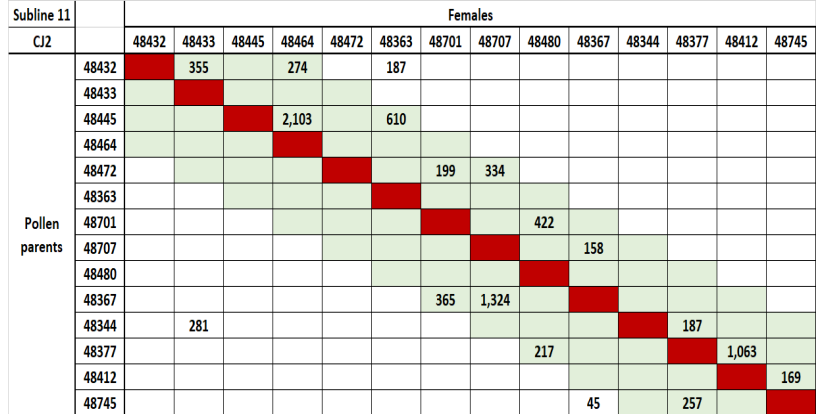

Figure 2

Example of a hypothetical crossing matrix. Numbers in cells are seed counts.

In total, the Douglas-fir breeding effort will be comprised of over 2,900 crosses, of which 2,500 have already been established in the field (Table 1). There are some complications in accounting for the numbers of crosses: some crosses were made and never planted, while some crosses were planted in two to four testing zones.

\section{Test Establishment Strategy}

A total of 136 tests are planned, of which 120 have already been established (Figure 3). Between five and eight tests are established per trial series, and between five and 13 tests per testing zone. Testing zones included either one or two trial series.

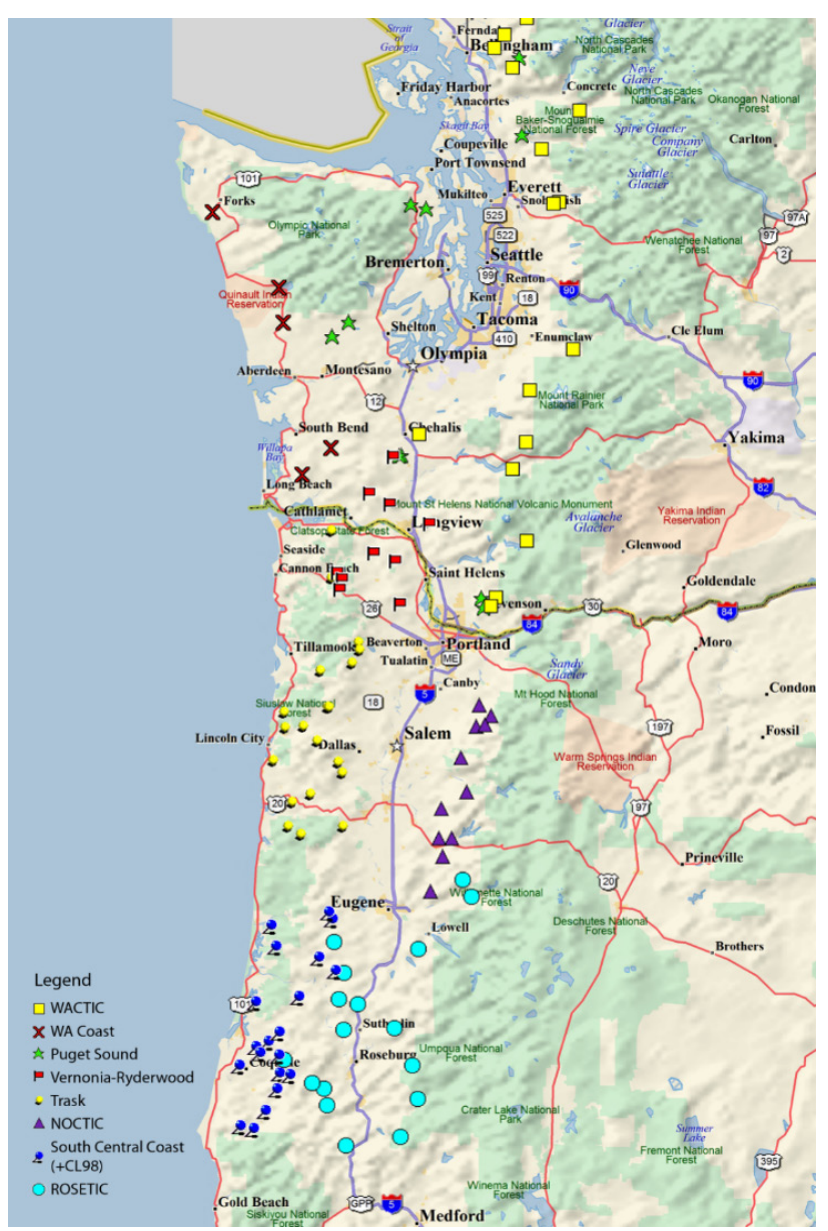

Figure 3

Location of cooperative second-cycle test sites. The different $2^{\text {nd }}$ cycle cooperatives are identified by different symbols in the legend.

Table 1

Status of cooperative $2^{\text {nd }}$-cycle Douglas-fir breeding populations as of 2020

\begin{tabular}{|c|c|c|c|c|c|c|c|c|c|c|c|c|}
\hline & \multirow[b]{2}{*}{ 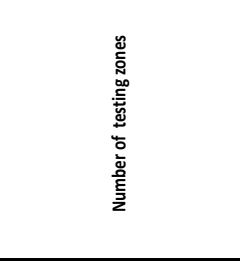 } & \multirow[b]{2}{*}{ 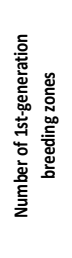 } & \multicolumn{6}{|c|}{ Number of Crosses and Parents } & \multicolumn{4}{|c|}{ Test Establishment } \\
\hline & & & 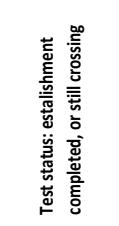 & 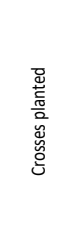 & 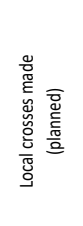 &  & 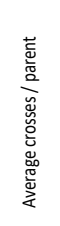 & 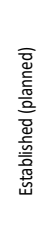 & 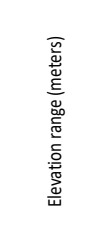 & 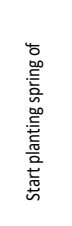 & 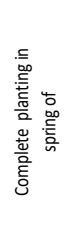 & 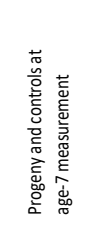 \\
\hline Washington Cascades & 2 (low-, high-elevation) & at & Completed & 291 & 300 & 311 & 1.87 & 16 & $181-970$ & 2006 & 2011 & 43,404 \\
\hline Puget Sound & 1 & 15 & Completed & 292 & 146 & 306 & 1.91 & 10 & $90-594$ & 2003 & 2009 & 23,988 \\
\hline Washington Coast & 1 & 4 & Completed & 116 & 137 & 142 & 1.61 & 5 & $100-345$ & 2008 & 2015 & 12,823 \\
\hline Vernonia/Ryderwood & 1 & 3 & Completed & 410 & 634 & 509 & 1.62 & 10 & $181-576$ & 2001 & 2005 & 33,548 \\
\hline North Oregon Cascades & 1 & 13 & Completed & 377 & 412 & 438 & 1.72 & 13 & $256-848$ & 2001 & 2005 & 37,313 \\
\hline Trask (Coast + Inland) & 2 (Coast, Inland) & 15 & Completed & 429 & 530 & 496 & 1.73 & 21 & $76-621$ & 2004 & 2007 & 55,267 \\
\hline South Central Coast & 2 (main, Swiss Needle Cast) & 11 & Completed & 604 & 739 & 483 & 2.50 & 20 & $85-454$ & 1998 & 2006 & 54,902 \\
\hline ROSETIC- UMpqua & 1 & 5 & Completed & 163 & 227 & 200 & 1.61 & 10 & $197-687$ & 2007 & 2010 & 15,289 \\
\hline ROSETIC- Roseburg Low & 1 & 11 & Completed & 217 & 218 & 249 & 1.74 & 7 & $354-682$ & 2012 & 2012 & 24,955 \\
\hline ROSETIC-Roseburg High & 1 & 11 & Completed & 106 & 91 & 130 & 1.63 & 5 & 848-1088 & 2012 & 2012 & 9,210 \\
\hline MEDTIC - Low & 1 & 9 & Crossing & (200) & $\begin{array}{l}107 \\
(180)\end{array}$ & 180 & (2.0) & (8) & $(454-850)$ & (2024) & (2024) & $(19,200)$ \\
\hline MEDTIC - High & 1 & 12 & Crossing & (200) & $\begin{array}{c}76 \\
(180)\end{array}$ & 180 & (2.0) & (8) & $(940-1670)$ & (2022) & (2022) & $(19,200)$ \\
\hline TOTAL Douglas-fir & 15 & 109 & & $\approx 2,900$ & $\approx 3,800$ & 2,660 & & 133 & & & & $\approx 349,000$ \\
\hline
\end{tabular}




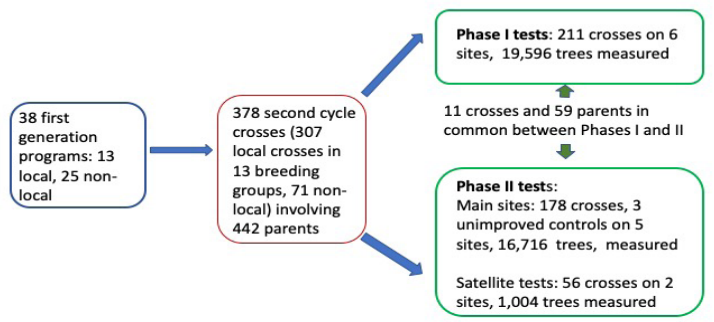

Figure 4

Schematic of a second cycle program starting from the firstgeneration base population

Trials established to date have contained from 50 to 283 full-sib crosses. In many cases crosses of a given program were planted in two phases, and the separate phases were linked by at least 10 common linker crosses (in addition to linker parents = same parent used in separate crosses in the separate phases).

Almost all tests have been established using alpha designs with incomplete blocks within complete reps (John and Williams 1995), to ensure efficient and unbiased comparison across families. Twenty trees are planted per cross per site, arranged in single-tree plots (i.e. 20 complete reps per site). Individual full-sib crosses are tested with a total 100-160 seedlings. Measure trees are surrounded by two buffer rows. A total of about 349,000 test trees are to be planted, with over 310,000 already planted. Thus the total number of trees planted in the second cycle will be around $15.6 \%$ of the total trees measured in the first generation; this is similar to the reduction of number of test trees in the CFGRP slash pine program (White et al. 2003). An example of how a second cycle program was assembled and established is shown schematically in Figure 4.

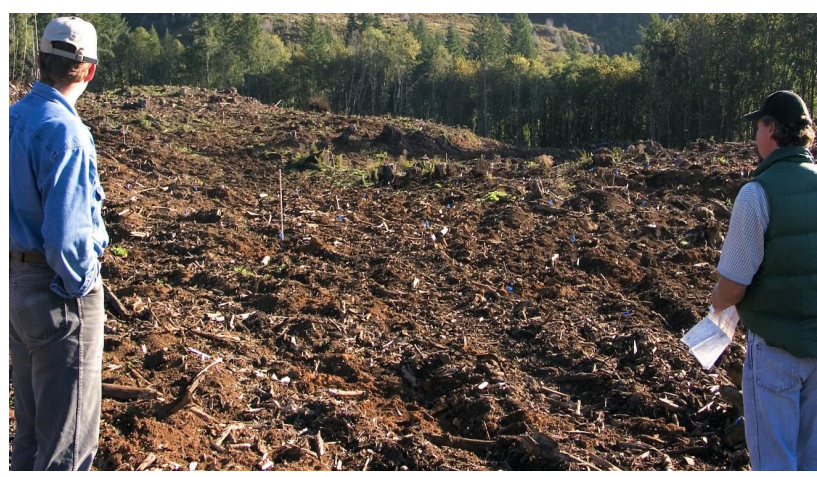

Figure 5

Example of mechanical site preparation prior to site establishment

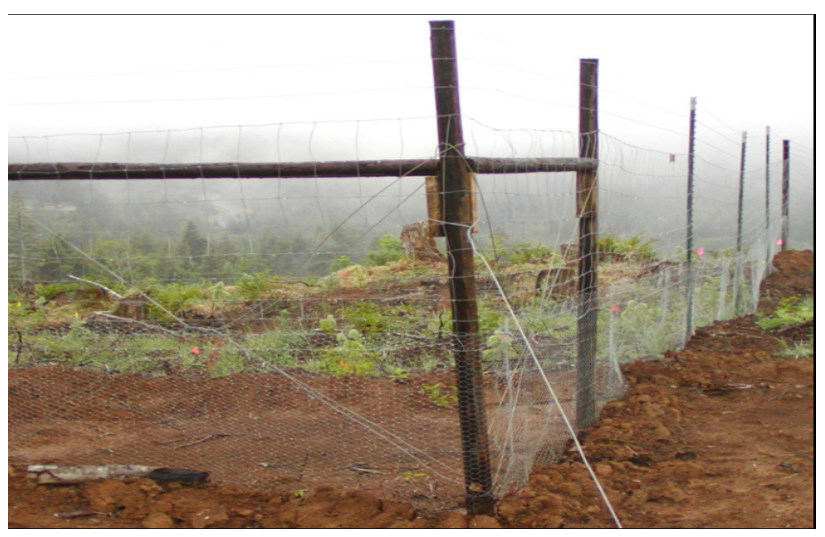

Figure 6

Woven wire fence construction showing corners reinforced with treated wooden posts

The use of farm-field sites (Woods et al. 1995) is generally not an option in western Oregon, Washington or California (except for pasture sites on small holdings purchased from private owners), so that progeny tests are typically planted on secondrotation or third-rotation forest sites. When pasture sites are used for tests, extra care needs to be taken to kill and break up the sod, address high rodent (mice and vole) populations and deal with aggressive weeds such as Himalayan blackberries. Most sites have been intensively prepared, removing slash accumulations since Douglas-fir thrives on mineral soil, sometimes with subsoiling to break up compaction as well, but generally with no stump removal (Figure 5). Stump removal is expensive and creates a lot of soil disturbance, and has therefore been avoided.

Sites are then fenced with $2.4 \mathrm{~m}$ tall woven wire fences for protection against browse from large herbivores (elk and deer) and small herbivores (typically rodents such as rabbits, hares and ground squirrels), as practiced in first-generation tests. These are substantial fences, with $3 \mathrm{~m}$ tall treated wooden posts at corners, metal T-posts at $3 \mathrm{~m}$ spacing, sturdy woven wire, and a chickenwire rodent barrier buried to $50 \mathrm{~cm}$ depth (Figure 6).

Seedlings are grown as one-year-old containerized seedlings in styroblocks: $515 \mathrm{~A}$ seedlings with 250 cc cell volume, or 615A seedlings with $336 \mathrm{cc}$ cell volume (Landis et al. 2010). Since there are almost no forestry research nurseries in the US PNW, these have all been grown in commercial seedling nurseries (with the majority grown on Vancouver Island, British Columbia). Seed are put in stratification by the end of December and sown after 45-60 days of stratification which has been successful for full-sib seed (though it is theoretically possible to stratify as long as 90 days - Stein and Owston 2008). All measure seedlings are individually labeled in the nursery with adhesive wrap-around labels (Figure 7a). After a season in the nursery, seedlings are typically $30-40 \mathrm{~cm}$ in height (Figure $7 \mathrm{~b}$ ).

Seedlings have mostly been lifted, randomized and packed in January, cold-stored just above freezing and planted within a few weeks after lifting (by the end of February), except for one high-elevation trial series where they were frozen and 


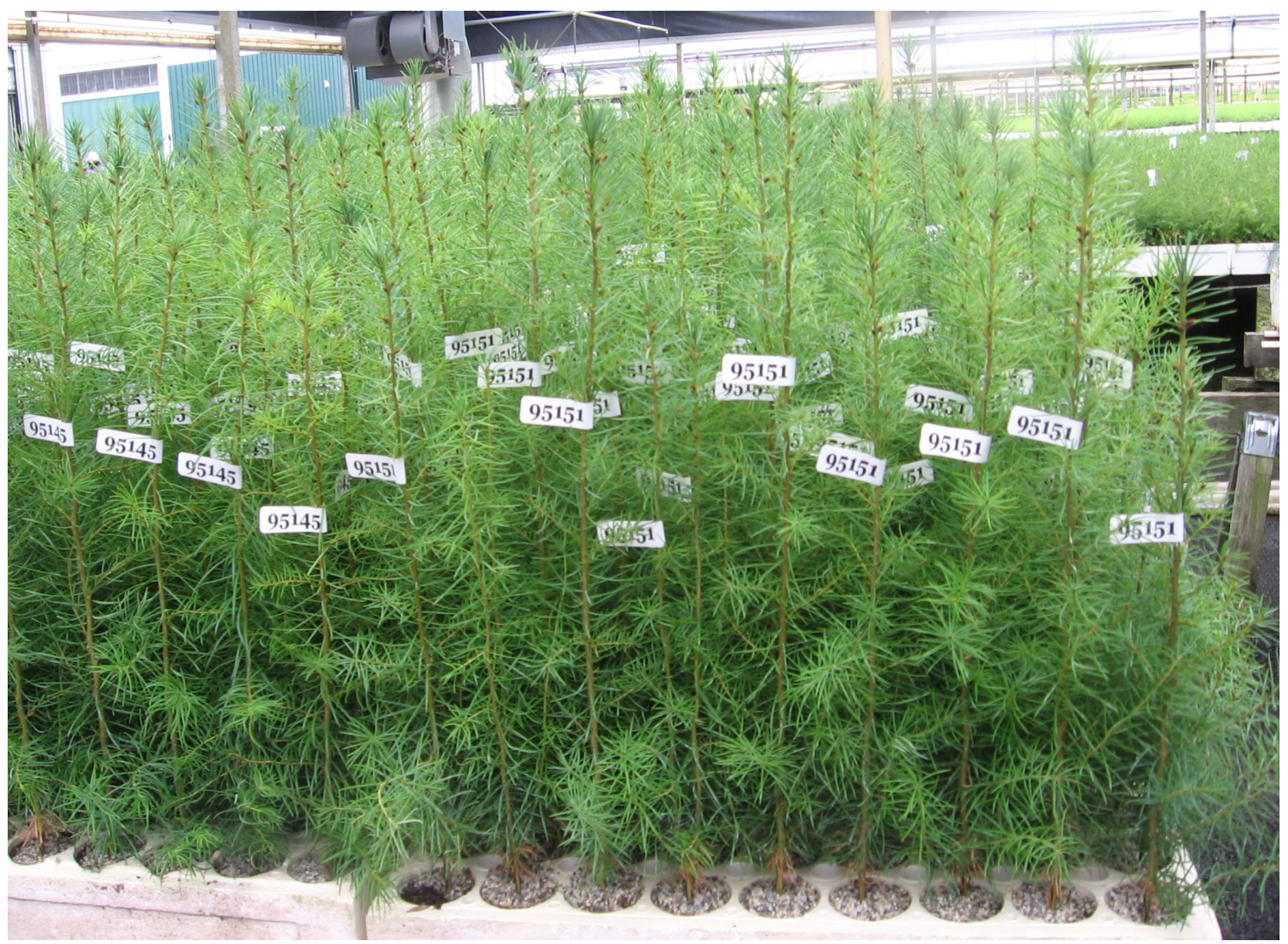

Figure $7 a$

One-year-old container seedlings are used for progeny testing. Photo shows a group of seedlings with nursery labels.

planted as late as April when snow has melted. The planting date could be as late as May for the highest elevation MEDTIC sites, to be installed in a couple of years. Fall planting of Douglas-fir (e.g. October) is a high-gain, high-risk strategy in the PNW: it can work very well if the seedlings get good soil moisture and warm soil temperatures at the same time, promoting root growth. However dry warm weather, rapid freezes before complete hardening occurs, or cold desiccating east winds, can all cause mortality. Fall planting has not been attempted in the second cycle.
Tree spacing has generally been $2.4 \times 2.4 \mathrm{~m}$ although a few test series have been established at $2.7 \times 2.7 \mathrm{~m}$ and $3 \times 3 \mathrm{~m}$ spacing. All sites in a trial series have been at the same spacing. Atypical planting spots (e.g. rocky ground, next to large tree stumps, wet spots) are planted to filler trees (not measured), and two rows of buffer trees are planted around the entire area of test trees. The fungal pathogen causing Laminated root-rot=LRR (Coniferiporia weirii) is widespread throughout the PNW and deadly to Douglas-fir; wherever possible sites with LRR are avoided, or small pockets are planted to species more resistant to the disease such as western red cedar. While LRR is long-lasting and almost impossible to eradicate from a site, it spreads relatively slowly. 


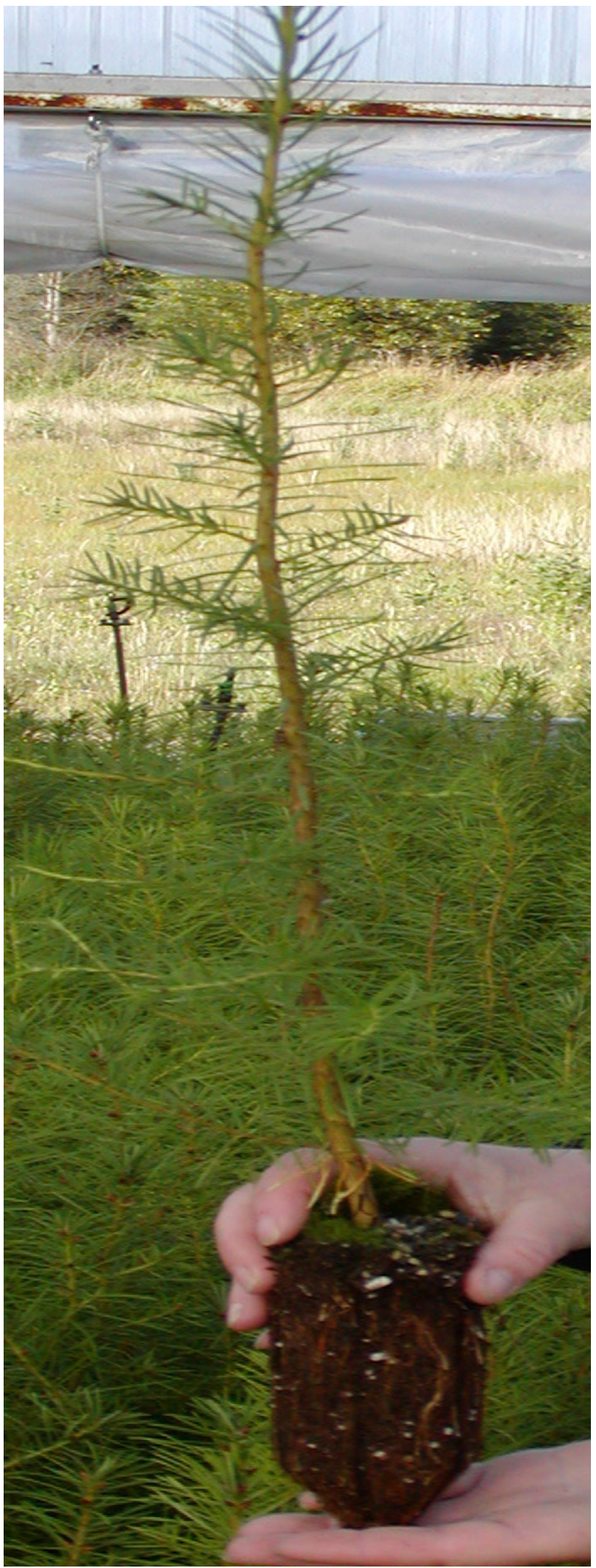

Figure $7 \mathrm{~b}$

Detailed view of seedling grown for progeny testing.

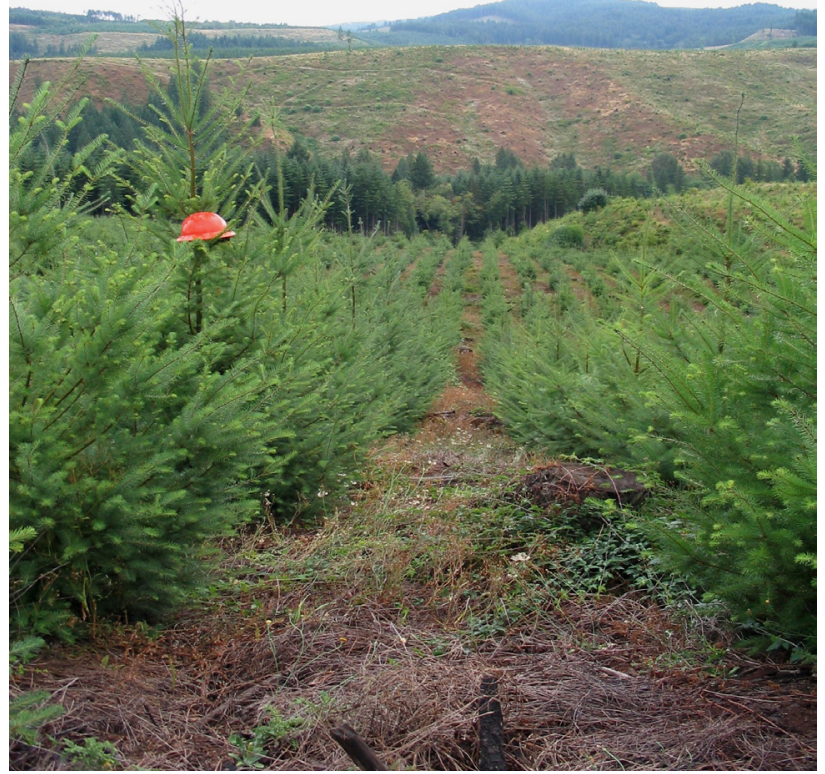

Figure 8

Example of high-quality second-cycle progeny test: excellent site preparation and well-controlled spacing

The goal has been to keep the tests weed-free for three years after planting, and control harmful competitors (such as cherry, big leaf maple, elderberry, red alder and other aggressive hardwoods) until crown closure (Figure 8). Competition control is important to improve survival (given the pronounced summer drought in the PNW), get trees to measurement size as soon as possible, and to reduce bias from environmental variation. Burrowing rodents especially gophers can cause severe damage by eating seedling or sapling roots, but have fortunately not been a major problem so far.

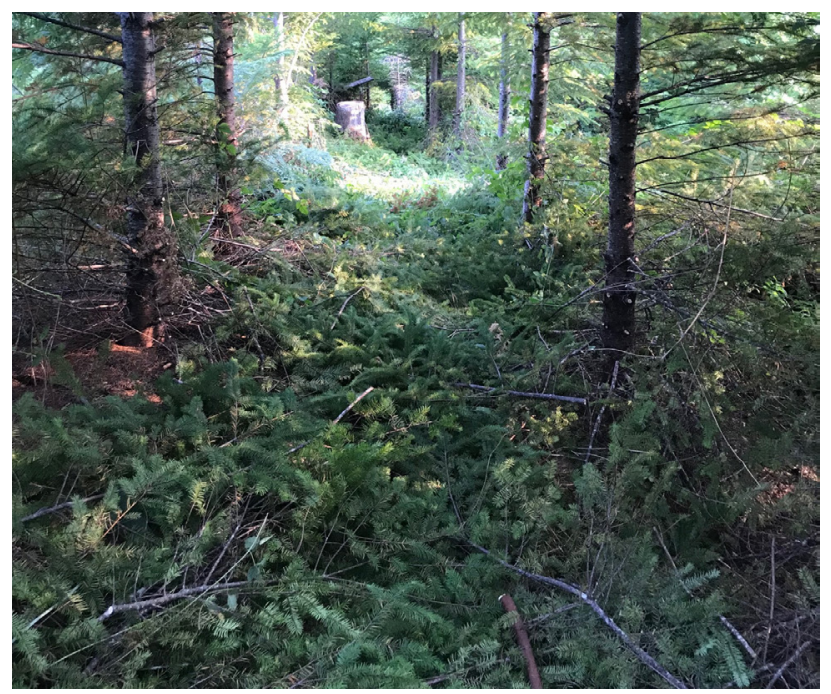

Figure 9

Access pruning of second-cycle test site in preparation for final measurement 


\section{MEASUREMENTS}

A detailed study on selection age by Ye and Jayawickrama (2012) confirmed that a final selection between age nine and 12 would give optimum gain, even for a 50 year rotation, when discount rates are taken into account. Tests are therefore measured at least twice, typically when the trees are seven and 12 years from seed. At those ages the trees were typically 3-6 meters and 8-12 meters tall, respectively. Prior to the second measurement, most sites have been access pruned along every other row to speed measurement and improve visibility (Figure 9).

The typical measurement schedule is:

Age-3 or 4: Progression of budburst, on a 1 to 5 rating score, when roughly $50 \%$ of the seedlings have broken bud. This is done on one or two sites per trial series.

Age-7: height (height pole), dbh, stem sinuosity in the second internode from the top, number of incidences of stem forking, number of incidences of ramicorn branching. Production and breeding orchards have generally been established based on age-7 information.

Age-12: height (vertex), dbh, stem sinuosity in the second internode from the top, number of incidences of stem forking, number of incidences of ramicorn branching, second flushing yes \no in current year.

Time of flight has also been measured on a subset of second cycle trees $(16,569)$, with another 4,000 trees due to be measured. This was shown to be a cost-effective, surrogate trait for ranking genetic trees for bending stiffness in Douglasfir (Cherry et al. 2008; Jayawickrama et al. 2011). Typically two or three sites are measured, for a total of about 25 trees per fullsib cross (Jayawickrama et al. 2009), using the TreeSonic device.

There were also some attempts to collect artificial fall cold hardiness data (Anekonda and Adams 2000) in some trial series, but operational results were far less consistent than obtained in research studies, and the effort was abandoned.

\section{DATA ANALYSIS}

Since 2003 NWTIC has adopted pedigree-based Best Linear Unbiased Prediction (BLUP) as the standard data analysis procedure, and this has been applied across all the second cycle testing programs, although with some slight refinements over time. Height and diameter are spatially de-trended prior to analysis, after clear demonstration of the improvements in model fit and prediction accuracy from spatial analysis (Ye and Jayawickrama 2008). Genetic gains are predicted for all parents, full-sib crosses and progeny (over the population mean), for height, dbh, volume, ramicorn branching, forking, sinuosity, acoustic velocity; gain of the population mean over unimproved controls are also estimated separately. In addition to predicted gains, accuracy and reliability of predicted breeding values, and the standard error of predicted gains are generated. For binary traits (incidence of second flushing) predicted breeding values are provided. Depending on cooperator interest, NWTIC sometimes performs combined analyses across

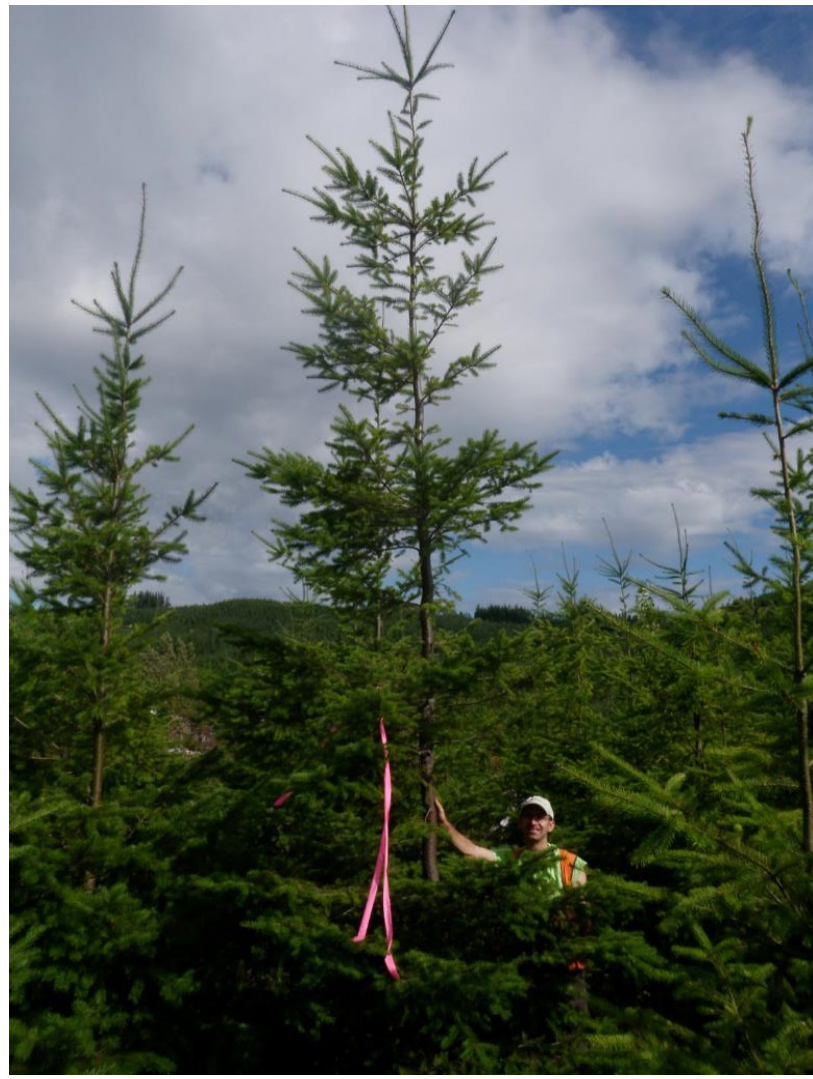

Figure 10

Second cycle forward selection

second-cycle programs when there is sufficient overlap of genetic material.

Following data analysis, cooperators are able to impose their preferred criteria to make forward selections (Figure 10).

\section{DEVIATIONS FROM BREEDING STRATEGY RECOM- MENDATIONS}

The concept of elite populations was implemented at first but generally abandoned, as it became apparent we would be investing extra resources on a subset of parents, without necessarily being able to make additional selections from them (for example, if we imposed a limit such as three forward selections per second-cycle parent). No polymix tests were established for GCA testing, and with one exception no full-sib block plots were established either.

\section{OBSERVATIONS AND CHALLENGES}

The delay of moving from first-generation to second-cycle largely worked in the favor of getting crosses made rather quickly, since the production and breeding orchards had grown and matured to the point of making crosses quickly. Larger Douglas-fir ramets produce much greater quantities of female and male strobili, making it possible to collect and apply larger amounts of pollen, and include five or more female strobili per isolation bag. Making crosses in operational orchards had the 
advantage of wide spacing, strobili close to the ground, and lots of ramets per clone.

Taller ramets also allowed for placing isolation bags higher off the ground and out of the frost zone. Spring frosts (March through early May) remain the greatest threat to successful Douglas-fir crossing, since female strobili are very sensitive to freezing temperatures from the time they are receptive till the conelets mature.

There were a few disadvantages of delaying second-cycle crossing. Crossing on tall ramets does incur the cost of hauling or renting lifts, and operating lifts can be slower than crossing from the ground or from short ladders. In one case, delay in the start of second-cycle breeding was such that the mature firstgeneration orchard was no longer needed for seed production and de-commissioned part way through the crossing program, so that crossing had to be done elsewhere.

While essential for preventing browse, building big-game fences, and removing them later when trees are above browse height, remains a major cost in testing Douglas-fir in the PNW, eventually reaching about $\$ 25$ per meter. As we move into third-cycle testing, there are efforts to reduce the cost by using lighter materials than the standard woven wire fence.

Newly-planted one-year-old Douglas-fir containerized seedlings break bud earlier than bare-root seedlings and established seedlings. This exposes them to a greater risk of damage from late spring frosts. However so far this only proved to be a problem on a handful of second cycle tests. Similarly only one test site had to be abandoned due to severe drought the summer after planting, when newly planted seedlings are most susceptible to mortality. A few sites proved to have more laminated root rot than expected, but fortunately almost all the measure trees stayed alive to the final data collection at age12.

All aspects of Douglas-fir breeding and testing are expensive compared to most tree breeding programs. Crossing often takes many years, access to remote field sites can be slow, working on rugged terrain is challenging, and above all needing to build fences increases costs substantially. Over the 20 years costs have gone up significantly, approaching $\$ 1,500$ per hectare for land clearing (slash removal), \$250-500 per completed cross, $\$ 3$ per position for layout and pinning test sites, $\$ 1$ per seedling growing and labeling cost and up to $\$ 3$ per tree for an age-12 measurement. Thus it is critical that breeding and testing strategies are lean and efficient: over-designing with superfluous crosses per parent, extra test sites, separate GCA (polymix) vs. full-sib tests, large elite populations, and frequent measurements, were generally jettisoned. At the time of breeding strategy development, genomic selection had not yet been proposed for forest tree breeding, and the technology has not been operational for the selections made to date. We do hope to implement genomic selection in the breeding program as the decade progresses.

This tree improvement program would not have been possible without the concept of breeding cooperatives pioneered in the 1960s, and cooperative production seed orchards begun in the 1970s, which has made it possible for both small and relatively large timberland owners to share in the costs and benefits of genetic improvement in an equitable fashion.

\section{CONCLUSIONS}

A large and intensive second-cycle breeding and testing program is nearing completion for coastal Douglas-fir in the US Pacific Northwest, supported by private forestry companies and many other timberland owners and managers operating in breeding and testing cooperatives. We anticipate that the results of this effort will be impacting forestry plantations on a landbase of 3 million hectares well into the $21^{\text {st }}$ century: $2^{\text {nd }}$ cycle production orchards are likely to be in use from around 2012 to as late as 2045, and rotations can be as long as 50 years.

\section{ACKNOWLEDGMENTS}

More than 50 years ago, Roy Silen (USFS) and Joe Wheat (Industrial Forestry Association), with the visionary support of timberland owners and managers, promoted and spearheaded a monumental first-generation tree improvement program on which genetic base this second cycle effort was entirely built. Many organizations (companies, agencies, tribes) have contributed to cooperative second-cycle Douglas-fir breeding and testing. Of the NWTIC's 50 current members, 37 are currently involved in advanced-generation cooperative Douglas-fir breeding; another nine previous cooperators were purchased or merged out of existence. Support has remained strong even through the severely depressed timber markets following the 2008 global financial crisis.

Jess Daniels was Director, and Dan Cress Geneticist, of the NWTIC at the time of formulating the second-cycle strategy; GR Johnson of the US Forest Service PNW Research Station, and Greg Johnson of Willamette Industries, played critical roles in getting the second cycle program underway. It would not be possible to list all the other people who have contributed to this effort, but some who played key leadership roles have been Jeff DeBell of the Washington Department of Natural Resources; Larry Miller of the Oregon Department of Forestry (ODF); Sara Lipow of ODF and Roseburg Resources; Jim Smith of The Timber Company (later Plum Creek Timberlands); Howard Dew and Bill Marshall of Cascade Timber Consulting; Al England, Rich Kelly, Bob Ohrn and Mike Crawford of the Bureau of Land Management; Bill Moore of Seneca Jones Timber Company; and Randall Greggs of Simpson Timber Company (later Green Diamond Resource Company). Helpful comments by three journal reviewers are gratefully acknowledged. 


\section{REFERENCES}

Anekonda T, Adams WT (2000) Cold hardiness testing for Douglas-fir tree improvement programs: guidelines for a simple, robust and inexpensive screening method. Western Journal of Applied Forestry 15(3): 129-136. https://doi.org/10.1093/wjaf/15.3.129

Cherry ML, Vikram V, Briggs D, Cress DW, Howe GT (2008) Genetic variation in direct and indirect measures of wood stiffness in coastal Douglas-fir. Canadian Journal of Forest Research. 38:2476-2486. https://doi.org/10.1139/x08-087

Howe GT, Jayawickrama KJS, Cherry ML, Johnson GR, Wheeler NC (2006) Breeding Douglas-fir. Plant breeding reviews. 27:245-353. https://doi.org/10.1002/9780470650349.ch6

Jayawickrama KJS, Carson MJ, Jefferson PA, Firth A (1997) Development of the New Zealand radiata pine breeding population. In: BURDON, R. D. and MOORE, J. M. (Ed.) "IUFRO '97 Genetics of Radiata Pine", Proceedings of NZ FRI-IUFRO Conference 1 to 4 December and Workshop 5 December, Rotorua, New Zealand. FRI Bulletin 203, New Zealand Forest Research Institute, Rotorua, New Zealand. pp. 217-225

Jayawickrama KJS, Ye TZ, Gupta R, Cherry ML (2009) Including Wood Stiffness in Tree Improvement of Coastal Douglas-fir in the US Pacific Northwest: A Literature Review and Synthesis. Research Contribution 50, Forest Research Laboratory, Oregon State University, Corvallis.

Jayawickrama KJS, Ye TZ, Howe GT (2011) Heritabilities, intertrait genetic correlations, GxE interaction and predicted genetic gains for acoustic velocity in mid-rotation coastal Douglas-fir. Silvae Genetica. 60:8-18. https://doi.org/10.1515/sg-2011-0002

Jayawickrama KJS, Miller LK, Cress DW (2013) Coastal Douglas-fir Controlled Crossing Guidelines. Tree Planters Notes 56(1): 60-73.

John JA, Williams ER (1995) Cyclic and computer generated designs. Chapman \& Hall/CRC Monographs on Statistics and Applied Probability (Book 38). 256 p. https://doi.org/10.1007/978-1-4899-7220-0

Johnson GR (1997) Site-to-site genetic correlations and their implications on breeding zone size and optimum number of progeny test sites for coastal Douglas-fir. Silvae Genet.. 46:280-285.

Johnson GR (1998a) Breeding design considerations for coastal Douglas-fir. USDA Forest Service PNW Research Station General Technical Report PNWGTR-411. 34 p. https://doi.org/10.2737/pnw-gtr-411

Johnson GR (1998b) Parental GCA testing: how many crosses per parent? Can. J. For. Res. 28: 540-545. https://doi.org/10.1139/x98-019

Johnson GR, Sniezko RA, Mandel NL (1997) Age trends in Douglas-fir genetic parameters and implications for optimum selection age. Silvae Genet. 46: 346 358.

Landis TD, Dumroese RK, Haase DL (2010) The Container Tree Nursery Manual. Volume 7, Seedling Processing, Storage, and Outplanting. Agric. Handbook 674. Washington, DC: U.S. Department of Agriculture Forest Service. 200 p

Lavendar DP, Hermann RK (2014) Douglas-fir: The Genus Pseudotsuga. The Forestry Communication Group, Oregon State University, Corvallis, OR, USA. $352 \mathrm{p}$.

Ritóková G, Shaw DC, Filip G, Kanaskie A, Browning J, Norlander D (2016) Swiss Needle Cast in Western Oregon Douglas-Fir Plantations: 20-Year Monitoring Results. Forests 2016 (7) 155. https://doi.org/10.3390/f7080155

Silen RR (1966) A simple progressive tree improvement program for Douglas-fir. USDA For. Serv. Res. Note PNW-45. $13 \mathrm{p}$

Silen RR (1978) Genetics of Douglas-fir. Research Paper WO-35, USDA Forest Service.

Silen RR, Wheat JG (1979) Progressive tree improvement program in Coastal Douglas-fir. J. For. 77: 78-83

St Clair JB, Howe GT, Kling JG (2019) The 1912 Douglas-Fir Heredity Study: LongTerm Effects of Climatic Transfer Distance on Growth and Survival. Journal of Forestry, 1-13. https://doi.org/10.1093/jofore/fvz064

Stein WI, Owston PW (2008) Pseudotsuga Carr. Douglas-fir. In: The Woody Plant Seed Manual. USDA Forest Service Agriculture Handbook 727. Pp.891-906.

White TL, Huber DA, Powell GL (2003) Third-cycle breeding strategy for slash pine by the Cooperative Forest Genetics Research Program. Proc. 27th Southern Forest Tree Improvement Conference, Oklahoma State University, Stillwater, Oklahoma. June 24-27 2003. p. 17-29.
Woods JH, Kolotelo D, Yanchuk AD (1995) Early selection of coastal Douglas-fir in a farm-field test environment. Silvae Genetica 44:178-186. Yanchuk AD (1996) General and specific combining ability from disconnected partial diallels of coastal Douglas-fir. Silvae Genetica 45(1):37-45.

Ye TZ, Jayawickrama KJS (2008) Efficiency of using spatial analysis in first-generation coastal Douglas-fir progeny tests in the US Pacific Northwest. Tree Genetics \& Genomes 4:677-692. https://doi.org/10.1007/s11295-008-0142-4

Ye TZ, Jayawickrama KJS (2012) Early Selection for Improving Volume Growth in Coastal Douglas-fir Breeding Programs. Silvae Genetica 61, 4-5, 186-198. https://doi.org/10.1515/sg-2012-0024 